\title{
Monitoring regional competitiveness using the BSC method: A case of the Czech national tourism organisation
}

\author{
Monika Palatková', Gabriela Hrubcová ${ }^{2}$ \\ e-mail: palatkova@czechtourism.cz, qhrug00@vse.cz \\ ${ }^{1}$ CzechTourism \\ ${ }^{2}$ University of Economics in Prague, Czech Republic \\ Palatková, M., \& Hrubcová, G. (2014). Monitoring regional competitiveness using the BSC method: \\ A case of the Czech national tourism organisation. Czech Journal of Tourism, 3(2), 107-126. DOI: 10.1515/cjot-2014-0006.
}

\begin{abstract}
The paper focuses on the adaption of the theoretical models of the regional tourism competitiveness to the conditions of the Czech Republic. The authors of this study analyze a newly emerged theoretical model of regional competitiveness monitoring with respect to the current data availability. The ultimate aim is to specify a proposal for the Czech national tourism organization (CzechTourism) in terms of practical usage and monitoring of the competitiveness model. The principal question is how and why to monitor the competitiveness of a tourist destination at the regional and national levels in the Czech Republic. The next step of the project is the conducting of the research, testing of the model and the implementation.
\end{abstract}

\section{Keywords}

Regional competitiveness, balanced scorecard (BSC), national tourism organisation, Czech Republic

JEL classification: M11, M31, L83 / Accepted: 11 August 2015 


\section{Introduction}

From the point of view of the national tourism organisation, the issue of the financial support is granted to the particular regions. The appreciation of the regional resources is probably the central point of the system of the prospective financial support. From the point of view of the regional tourism organisations, the competitiveness monitoring should provide information on the competitive position and positioning, as well as the information about the basic indicators of the BSC (The Balanced Scorecard) perspectives using the BSC method. For regional tourism organisations the model should serve as an important managerial tool of the tourism development. The question is how to harmonize the BSC perspectives at the national and regional level with respect to the tourism national marketing strategy of the Czech Republic.

As the development of tourism in the Czech Republic has been supported by the funds of the European Union from 2007 to 2013 and afterwards, many projects and investments have been financed partly by the funds and partly by the national public budget. One of the important issues is the evaluation of the hard as well as the soft investments regarding tourism development and the benefits for all the different interested groups.

The results of the paper are part of the project "Tourism competitiveness of the Czech Republic regions and the possibility of the marketing measures performance evaluation using the BSC method". The project was co-funded and supported by the Czech national tourism organization (CzechTourism) and by the University of Business in Prague. The aims and scope as follows: 1. Analysis of the available models of competitiveness monitoring and evaluation; 2. Design of the methodology and model for competitiveness monitoring and evaluation; 3. Link up of the competitiveness model at the regional and local level with the BSC model; 4. Pilot verification - comparison of three Czech regions within domestic and incoming tourism.

\section{Theoretical basis}

The term competitiveness is very common, but its explanation can vary extensively. Not only the different points of view are emphasizing several different aspects in the literature (e.g. financial, social welfare or aspect of sustainability), but also various levels and sorts of competitiveness itself. Modification of each definition of competitiveness differs and depends mostly on whether determined at the micro-level (individual entities), the meso-level (delimited by the unit at the regional level, the sector) or the macro-level (country level). At the most general level, it is possible to understand competitiveness as the ability to achieve the objectives - the ability of efficient, flexible and innovative way to use the resources in the way to meet the interests of all stakeholders - customers, employees, owners, managers and residents. During the last few years, the balance of the resources that affect the competitive advantage endurance shifts to the intangible resources. According to Barney (1991), to achieve the competitive advantages, the resources must be valuable, difficult to reach at the sources market and difficult to replace 
and reproduce. The weight of the tangible resources in tourism is still relatively high, especially because of the mentioned characteristics. Nevertheless, they are not the assurance of a future competitive advantage (Palatková et al., 2014).

The concept of competitiveness of the destination in the project is based on the concept of the ability to conduct the offered products and services on the international and domestic tourism market. This should be done in the way to achieve economic and non-economic effects for residents and other stakeholders' of the destination. The assessment of the competitiveness in the project includes mainly the economic aspect, but works with the political aspect and dimension of the sustainable development as well. To assess the competitiveness of the company as well as the destination, the authors of this article determine various indicators and different models. To assess the competitiveness of the regions, they use the objective and subjective data and factors, including the perception of the destination.

Porter $(1993,1994)$ represents the broad and international context of competitiveness since 90's. The most important approaches to the competitiveness measurement involve the Porter's five forces analysis (Porter, 1993, 1994) and Porter's Diamond of National Competitiveness (Porter, 1990). Another approaches are Poon's Competitiveness Concept (Poon, 1993), Bordas Model and WES model (Schumpeter, 2004). In addition, one of the most comprehensive models was elaborated by Ritchie and Crouch (2003). It is based on the above-mentioned Porter's diamond model, however, it significantly extends and adapts the tourism industry. The model evaluates the competitiveness of the destinations on five internal and two external areas. Among the five areas there are the internal factors and resources as well as the key resources and attractiveness, marketing and management of the destination, the destination tourism policy, planning and development and empowering other factors (e.g. position).

The only institution currently engaged in evaluating competitiveness in the international tourism is the World Economic Forum (Blanke \& Chiesa, 2013), monitoring the competitiveness in tourism through the Travel and Tourism Competitiveness Index (TTCI). OECD (Organisation for Economic Co-operation and Development) is currently developing a set of indicators that should cover the whole issue of competitiveness evaluation from the area of evaluation resources, ability of their use and a transformation in quality products to evaluation of public policies and the subsequent evaluation of the performance of tourism (Dupeyras \& MacCallum, 2013).

The Keyser-Vanhove model of tourism competitiveness provides a greater opportunity for including external factors, in particular government policies, into the competitiveness analysis. The general opinion among economists today is that while tourism may contribute to an increase of the country's wealth, practical examples warn that this is not always necessarily so. It has to do with those destinations that are not successful in transforming tourism into a profitable industry or manage to do so only in a short run (Vanhove, 2005).

Cunha and Cunha (2005) describe four dimensions covered by the regional model within the tourism clusters: the meta level (esp. social cohesion), the macro level (e. g. direct and indirect tourism policies, regulation framework), the mezzo level (relations to 
destination management organisation (DMO) and other institutions, alliances and nets among the cluster companies, cooperation and interaction) and the micro-level. The methodology used during the development of the model uses Ritchie and Crouch model (2003), multifactor ranking research studies (Blanke \& Chiesa, 2013) and Dwyer and Kim model (2003). It highlights the importance of the different competitiveness dimensions, cost-benefit analysis (CBA) presented by Adler and Posner (2001) or Mishan and Quah (2007) and evaluation of resources (RBV, resource-based view) as presented by Lee and King (2009). Since the term competitiveness is a real issue concerning its content as well as the implications, it is a tricky task to prepare a relevant competitiveness model at the regional level of a tourism destination. The presented model primarily stresses the point of view of a destination management company. Nevertheless, it tries to cover various levels of competitiveness and its stakeholders/representatives.

The motive for creating the BSC (Balanced Scorecard) by Kaplan and Norton (2005) was a belief that relying on the summary financial indicators limits the company's potential to generate future value. BSC is a strategy performance management tool applied mainly in the corporate practices and has not been used very much in the marketing management of the destination, yet. This method retains the traditional financial indicators and adds the new scale drivers for the future performance: Financial Perspective, Customer Perspective, Perspective of internal processes, Perspective of learning and growth. Since it deals with the performance evaluation of the destinations from four different perspectives, it might be used very effectively. The advantage takes into account the financial and non-financial objectives and assessment process for obtaining intangible assets and resources which are important for the further development of the destination. As it has been mentioned above, the connection to competitiveness is obvious. BSC method sets goals and metrics in the field of achieving competitive advantages (in terms of knowledge and experience of motivated employees, improving the quality of processes and creating the value for current and future customers), which with a certain time lag may be reflected in the success of the company or destination (Palatková et al., 2014).

\section{Methodology}

Monitoring of the regional competitiveness in tourism destinations is considered to be a real challenge. The presented paper aims to formulate a guiding framework on setting up the model of regional competitiveness in the tourism destination and to emphasize the point of view of the national tourism organization. The mentioned model can assist national, regional or local governments and industry practitioners to enhance destination competitiveness and achieve a long-term sustainability and efficiency. The regional and national standpoints are crucial in terms of definition, measurement and evaluation of individual indicators of regional competitiveness. The results of measurement and evaluation can serve as an important signal of a competitive position, positioning and as a managerial tool for national, as well as regional tourism organisation. 
The paper tries to include all the relevant aspects and indicators of competitiveness at the regional level, regardless of its availability up to the present. To apply the competitiveness model in practice, the final broad version of the competitiveness model has to be transformed into the effective managerial tool. To manage the destination strategy, the strategy map (Kaplan \& Norton, 2008) and the balanced scorecard model (BSC) can be used in a very relevant way (Kaplan \& Norton, 2005). This is why the crucial indicators and relations within the competitiveness model are transposed into the BSC model. The BSC model is constructed from the national tourism organization point of view.

The starting point is a detailed analysis of the available model for competitiveness monitoring and evaluation at the regional level in order to launch a draft of the regional competitiveness model. The next step is a design of the methodology and model for the monitoring and evaluation of competitiveness. Finally, there is a competitiveness model proposal and connection of the model to the BSC to achieve relevant values.

\section{Regional competitiveness concept}

from the conceptual point of view, the proposal of the aspects competitiveness model as well as the follow-up balanced scorecard (BSC) model includes the following aspects:

- Model covers the regional level, interconnects the local and the national level, as well as the micro- and macro level.

- Domestic and incoming tourism are included in the model despite the differences in the regional spread and other parameters.

- Model distinguishes between comparative and competitive advantages. The socio-cultural, economic and environmental dimensions are taken into consideration according to the concept of the tourism destination sustainability.

- Construction of the model envisages the dynamic approach to the competitiveness, combining the input and output factors.

- Model tries to cover the four main groups of stakeholders active in a tourist destination, specifically in the destination management companies (tourist organisations), the private sector stakeholders, the (potential) visitors and tourists and the residents. The mentioned players perceive the term competitiveness in different way.

- Among all the analysed models presented in the previous theoretical part, two models highlights the competitiveness model the most: Ritchie and Crouch model (for the regional level) as well as the approach designed by the OECD (for the national level).

- The up to date findings on competitiveness are covered by the model, especially in terms of innovation, knowledge networks, CRM systems and creative industries. 


\section{Competitiveness measurement and data}

Ritchie and Crouch model (2003), the OECD competitiveness indicators (Dupeyras \& MacCallum, 2013), the TTCI methodology (Blanke \& Chiesa, 2013) seem to be a base for the model, supplemented by new indicators referring to the innovation-driven and the knowledge and creativity-driven stage of competitiveness.

- Combination of objective (hard) and subjective (soft) data are used in the proposed model because of the different stakeholders and their perception of competitiveness within a tourist destination.

- Despite the fact that the regional level represents the central point of the national marketing management system of a tourist destination, the sampling, acquisition, measurement and evaluation of competitiveness indicators are difficult, especially in the field of economic impacts of tourism.

- The authors of this study defined the four pillars of the model, split them into the sub-pillars and each of them valued by the weight. The first pillar is based on the resources, the second one on the tourism demand and the third one on the residents. The fourth pillar, which is focused on the resources performance, is considered to be the crucial managerial part of the model.

- The individual indicators are prioritized according to the importance and availability in the long-term.

- Concerning the methods of data collection, their processing and the method of evaluation of the results, there is a big lack of data at present as it is shown in Table 1 below. As far as the evaluation of the results is concerned, the five-point scale is supposed to be applied.

The proposed model itself cannot be the end of the process to be able to meet all the managerial tasks. That is the reason why managers of the destination should consider the model to be a source of indicators that are relevant to evaluate and draft the destination policy.

\section{Results}

\section{Competitiveness model}

Launching and completing the competitiveness model is an important turning point in the process of the project development, but it is not the result itself. The authors of this article divided the proposed model into four pillars as it is depicted in Figure 1 below.

1. The first covers the set of resources - natural, cultural, human and capital resources and the endowments in terms of their qualitative and quantitative parameters.

2. The second pillar deals with the visitors, e.g. the visitor portfolio, perception of the clients or demand monitoring system connected with the CRM system. 
Table 1 The competitiveness model and BSC

\begin{tabular}{|c|c|c|c|c|c|}
\hline Group of indicators & $\begin{array}{l}\text { Respondents / } \\
\text { Target group }\end{array}$ & $\begin{array}{l}\text { Main methods of } \\
\text { data collecting }\end{array}$ & Data obtained & Evaluation & $\begin{array}{c}\text { Data } \\
\text { availability }\end{array}$ \\
\hline \multicolumn{6}{|l|}{ RESOURCES } \\
\hline Natural resources & $x$ & sec data mainly & quant data & scale $1-5$ & $\begin{array}{l}\text { data to be } \\
\text { adapted }\end{array}$ \\
\hline Endowments & $\mathrm{x}$ & sec data mainly & quant data & scale $1-5$ & $\begin{array}{l}\text { data to be } \\
\text { adapted }\end{array}$ \\
\hline Human capital & $\begin{array}{l}\text { DMO, private } \\
\text { sector }\end{array}$ & prim / sec data & quant data & scale $1-5$ & $\begin{array}{l}\text { data on bus. } \\
\text { activity only }\end{array}$ \\
\hline Capital resources & DMO & sec data mainly & quant data & scale $1-5$ & $\begin{array}{l}\text { data to be } \\
\text { adapted }\end{array}$ \\
\hline TOURISM DEMAND & visitors / DMO & $\begin{array}{c}\text { FTF / focus } \\
\text { group / on-line } \\
\text { monitoring }\end{array}$ & quant data & $\begin{array}{l}\text { various } \\
\text { approaches }\end{array}$ & partly available \\
\hline Visitors portfolio & visitors & prim / sec data & quant data & $\begin{array}{c}\text { various } \\
\text { approaches }\end{array}$ & $\begin{array}{c}\text { yes except of } \\
\text { data on visitors } \\
\text { loyalty }\end{array}$ \\
\hline $\begin{array}{l}\text { Perception of the } \\
\text { destination }\end{array}$ & visitors & prim / sec data & $\begin{array}{l}\text { quant / qual } \\
\text { data }\end{array}$ & $\begin{array}{c}\text { various } \\
\text { approaches }\end{array}$ & $\begin{array}{c}\text { yes except of } \\
\text { data on brand } \\
\text { value }\end{array}$ \\
\hline $\begin{array}{l}\text { Demand monitoring } \\
\text { system }\end{array}$ & DMO & prim data & $\begin{array}{l}\text { quant / qual } \\
\text { data }\end{array}$ & $\begin{array}{c}\text { various } \\
\text { approaches }\end{array}$ & no \\
\hline CRM & $\mathrm{DMO}$ & prim data & $\begin{array}{l}\text { quant / qual } \\
\text { data }\end{array}$ & $\begin{array}{c}\text { various } \\
\text { approaches }\end{array}$ & no \\
\hline RESIDENTS & residents & FTF / focus group & $\begin{array}{c}\text { quant / qual } \\
\text { data }\end{array}$ & scale $1-5$ & no \\
\hline Quality of life & residents & prim / sec data & $\begin{array}{l}\text { quant / qual } \\
\text { data }\end{array}$ & scale $1-5$ & $\begin{array}{l}\text { data to be } \\
\text { adapted }\end{array}$ \\
\hline $\begin{array}{l}\text { Satisfaction with } \\
\text { tourism }\end{array}$ & residents & prim data & qual data & scale $1-5$ & no \\
\hline $\begin{array}{l}\text { Tourism economic } \\
\text { effects }\end{array}$ & residents & prim data / CSO & quant data & scale $1-5$ & no \\
\hline $\begin{array}{l}\text { Residents relations } \\
\text { management }\end{array}$ & residents & prim data & $\begin{array}{c}\text { quant / qual } \\
\text { data }\end{array}$ & scale $1-5$ & no \\
\hline $\begin{array}{l}\text { RESOURCES } \\
\text { PERFORMANCE }\end{array}$ & $\begin{array}{l}\text { DMO / private / } \\
\text { public players }\end{array}$ & $\begin{array}{l}\text { FTF / on-line } \\
\text { monitoring }\end{array}$ & qant data & $\begin{array}{c}\text { mainly scale } \\
1-5\end{array}$ & partly available \\
\hline $\begin{array}{l}\text { System of destination } \\
\text { marketing management }\end{array}$ & DMO & prim / sec data & quant data & scale 1 - 5 & partly available \\
\hline $\begin{array}{l}\text { Strategic management } \\
\text { / Tourism policy }\end{array}$ & DMO & prim / sec data & quant data & scale $1-5$ & partly available \\
\hline MKT activities & $\begin{array}{l}\text { DMO + private } \\
+ \text { public players }\end{array}$ & prim / sec data & quant data & scale $1-5$ & partly available \\
\hline $\begin{array}{l}\text { BENEFITS for the } \\
\text { public/private players }\end{array}$ & $\begin{array}{c}\text { DMO + private } \\
+ \text { public players }\end{array}$ & prim / sec data & quant data & scale $1-5$ & partly available \\
\hline
\end{tabular}

Source: own figure based on Palatková et al. (2014) 
3. Residents are included in the model as they are important with respect to the destination perception, production and distribution of economic and other effects raised by tourism.

4. The management issues are comprised in the fourth pillar called "ability to use resources". The management system, strategic marketing and individual marketing activities are projected in this part of the competitiveness model to show how the destination (destination management organisation) treats the assets covered by the previous pillars.

5. The proposed evaluation for the resources amount up to $40 \%$, for the tourism demand $25 \%$, for the residents $10 \%$ and for the ability to use resources $25 \%$.

\section{Purpose of the model}

The model should serve as an important source of information and base for the decision-making process and management at the national and regional level. This model was developed as a maxi-version, but the authors of this study are aware of the fact that there is no chance to implement it right now in practice in all the regions of the Czech Republic. The analysis of the available sources shows that most of the data are not available at all or they are just partly available. Either the scope of the collected data is not sufficient or the methodology of the collection of the data is different among the regions.

\section{Analysis of the Czech regional strategic documents in the period of 2007-2013}

The analysis of the regional strategic documents covers the administrative units, standing independently in the Czech system of decentralized public administration. According to the results of the analysis of the regional strategic documents in the period of 2007 - 2013, the following issues have been covered in 13 Czech administrative regions (these are not tourism marketing regions):

1) The analytical parts of the surveyed documents are voluminous in contrast to the proposal parts.

2) The term "competitiveness" can be found in different context in all of the examined strategic documents.

3) The goals are not clearly defined in terms of their quantification.

4) There are no defined indicators in terms of competitiveness.

5) No quantification or indicators for measuring and monitoring the goals are defined in the strategic documents.

6) There is no methodology how to monitor and measure the basic indicators of supply and demand.

7) No financial aspects are included.

8) There is no residents' point of view.

9) No explicit expenditure for marketing research and monitoring of the indicators is mentioned. 
Figure 1 Competitiveness Monitoring - Regions / Locations

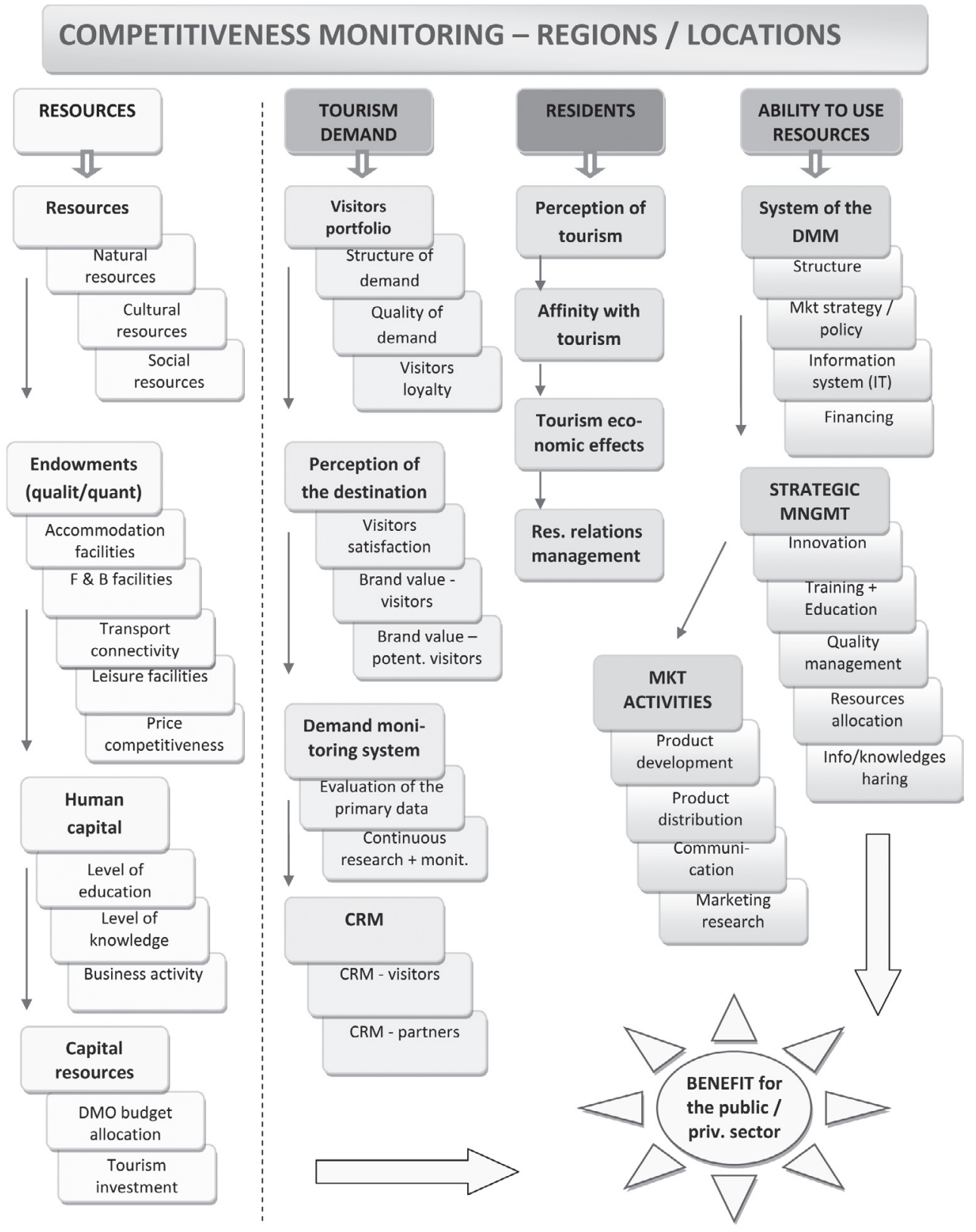

ECONOMICENVIRONMENT Political environment Ecological environment LEGISLATIVE ENVIRONMENT Social environment Technical/Technological env.

Source: own figure based on Palatková et al. (2014) 
The results of the previous analysis showed that despite using the term "competitiveness" as one of the success, there were no indicators defining the scope and depth of this term. Using the proposed competitiveness model should eliminate the deficit in monitoring and measuring basic characteristics of competitiveness in the field of demand, supply and residents. In this context the term competitiveness gains its political relevance.

\section{Political issues}

Competitiveness and sustainability are usually the central points of modern tourism policies at both regional and national levels. The competitiveness model, even if in the reduced form and with the set of the indicators should turn into the fundamental base for destination marketing management and decision-making process. The full or reduced version of the model should fulfil several tasks at the national and regional level in the Czech Republic. The main profit for the institutions at the national as well as the regional level is summarized as follows:

\section{National level - CzechTourism (Ministry of Regional Development)}

- System usable for monitoring and evaluation of achievements of national tourism policy and destination marketing strategy of the Czech Republic.

- Set of the indicators potentially usable in the proposed national tourism law - in terms of costs (public budget subsidies) and benefits (indicators of demand, residents and supply).

- Setting up the system of indicators facilitates the decision in providing the composition of the financial and/or non-financial subsidies within the national and the regional level.

- Unified system of tourism development indicators provides valuable information on the budget allocation in terms of input-output relations. It facilitates the decision on the budget allocation in the product development, communication and distribution, including the foreign representative offices.

- The broad competitiveness model enables to define the key performance indicators and transform the competitiveness model into the BSC platform that serves as reliable and relevant managerial tools for the national tourism organisation (CzechTourism).

\section{Regional Level - regional governments (administrative units)}

- Information on the competitiveness serves as the crucial criteria of all regional strategic documents (destination strategies). The indicators enable to connect tourism performance with the indicators of the regional development on the basis of the causal link.

- Information on residents' satisfaction is important for the regional governments and the regional elections respectively. The residential affinity and attitude towards tourism development is believed to be a decisive factor in the long-term period. 
- Basic system of indicators at the regional level can show the way in which the DMO; works and to search for the new concepts and innovative ways.

- Since the set of indicators covers the financial aspects, it meets some requirements of the smart public administration.

- Defined indicators represent the base for creating the strategic documents, their monitoring and control.

- Information on position and positioning related to the Czech regions can be an additional value of the model and its measurement.

Providing information on benefits for the public and private sector as the result of a successful destination marketing management system can be a relevant argument in the tourism budget decision-making process at the regional level.

\section{How to implement the bsc model?}

According to Kaplan and Norton (Kaplan \& Norton, 2005), the BSC model is the vision of the company, creates the holistic model of the strategy and provides the feedback on company performance for all employees. The BSC model represents the complement to the strategy map not only in the private company (Kaplan \& Norton, 2008), but also in the tourist destination. The destination management system pursues the system of performance and competitiveness and enables to connect the operational and strategic processes and activities. To set up a monitor strategy of the tourism destination, the strategy map and the BSC model (connected to the competitiveness model) seem to be important.

The BSC model allows covering various groups of stakeholders, time periods or strategic and operational goals and processes by using the four (five) perspectives with respect to the national tourist destination (Kaplan \& Norton, 2004; Kaplan \& Norton, 2005; Kaplan \& Norton, 2008):

1) Stakeholders'perspective - the private and public stakeholders and their satisfaction with the activities of (national) tourism organisation.

2) Financial perspective. The partial indicators based on tourism satellite account, national balance of payment or special research studies focused on the regional level and/ or other financial indicators of accommodation facilities can be used.

3) Visitors' perspective and residents' perspective - satisfaction of visitors and residents, e.g. in terms of interaction or services accessibility. Visitors' perspective includes goals such as the value for money, the accessibility, the CRM system implementation, or their satisfaction. Residents' perspective is connected to the satisfaction with tourism effects and with the strengthening of national (regional) identity.

4) Internal processes perspective integrates the key process in the destination and/or the national tourism organisation in order to achieve the goals in the above mentioned perspectives. 
5) Learning and growth perspective covers the human resources, systems (information capital) and climate (the organisational capital) in the destination and/or the national tourist organisation.

Referring to the performance of the organization (destination): “... the strategy map and scorecard communicate the outcomes to be accomplished, allowing innovation at middle and lower levels of the organization to find new and different ways to achieve the targeted performance." (Kaplan, 2012, p. 542).

Kaplan and Norton (2005) defined three principles that transfer the strategy into measurement:

1. The causal link - relation between the cause and result.

2. The driving forces of performance.

3. The relation to financial aspects.

The causal links between the selected indicators inside the competitiveness model are primarily the links between the indicators summarized in Table 2. Basically, the relations between the resources and demand, as well as the resources and residents are emphasized from the point of view of the destination. The ability, to use resources related to the tourism demand, residents and private and public sectors, is decisive from the point of view of the regional (local) or national tourism organisations. The relations and casual links serve as an important tool for the destination management organisations.

Table 2 Key efficiency indicators

\begin{tabular}{|c|c|c|}
\hline Index & Index & Relations (examples) \\
\hline \multirow{8}{*}{ RESOURCES } & \multirow{2}{*}{ Resources } & natural resources/accommodation facilities \\
\hline & & number of visitors/ cultural resources \\
\hline & \multirow[t]{2}{*}{ Endowments } & $\begin{array}{l}\text { price competitiveness / number of monuments listed in UNESCO } \\
\text { WHL }\end{array}$ \\
\hline & & price competitiveness/ destination brand value \\
\hline & \multirow{2}{*}{ Human capital } & level of education / benefit for private sector \\
\hline & & business activity / quality of demand \\
\hline & \multirow{2}{*}{ Capital resources } & DMO budget allocation / benefit for private sector \\
\hline & & business activity / brand value \\
\hline \multirow{6}{*}{$\begin{array}{l}\text { TOURISM } \\
\text { DEMAND }\end{array}$} & \multirow{2}{*}{ Visitors portfolio } & structure of demand / ability to use resources (cost for mkt research) \\
\hline & & visitors loyalty / quality management \\
\hline & \multirow{2}{*}{$\begin{array}{l}\text { Perception of the } \\
\text { destination }\end{array}$} & perception of the destination/ cost for communication campaigns \\
\hline & & perception of the destination/ financing \\
\hline & \multirow{2}{*}{$\begin{array}{l}\text { Demand monitoring } \\
\text { system }\end{array}$} & evaluation of primary data / resources allocation \\
\hline & & CRM / quality management \\
\hline
\end{tabular}


Monika Palatková, Gabriela Hrubcová • Monitoring regional competitiveness using the BSC method...

\begin{tabular}{|c|c|c|}
\hline Index & Index & Relations (examples) \\
\hline \multirow{6}{*}{ RESIDENTS } & \multirow{2}{*}{ Perception of the tourism } & perception of the tourism / mkt strategy (policy) \\
\hline & & perception of the tourism / financing \\
\hline & \multirow{2}{*}{ Affinity with tourism } & affinity with tourism / structure of demand \\
\hline & & affinity with tourism / endowments (e.g. accommodation) \\
\hline & \multirow{2}{*}{$\begin{array}{l}\text { Tourism economic } \\
\text { effects }\end{array}$} & number of employees in tourism / financing (DMO) \\
\hline & & tax revenue form tourism / endowments \\
\hline \multirow{6}{*}{$\begin{array}{l}\text { ABILITY } \\
\text { TO USE } \\
\text { RESOURCES }\end{array}$} & \multirow{2}{*}{ System of DMM } & private share on financing mkt activities / brand value (perception) \\
\hline & & quality of mkt strategy / visitors loyalty \\
\hline & \multirow{2}{*}{ Strategic management } & innovation / quality of demand \\
\hline & & resources allocation /brand value (perception) \\
\hline & \multirow{2}{*}{ MKT activities } & product development / benefit for private sector \\
\hline & & product distribution \\
\hline
\end{tabular}

Source: own figure

The indicators of the BSC can be divided in two subgroups: pre-indicators and post-indicators (related indicators). The pre-indicators count for driving forces of performance of destination management organization and reflect the uniqueness of strategy of the destination or DMO. The post-indicators represent the results, e.g. economic effects of tourism, visitors' satisfaction and visitors' loyalty. The mixture of both sorts of indicators is shown in Figure 3. The BSC at the regional level is the projection of the individual indicators of the regional competitiveness model (Table 2). The pillars of the model are transformed into the perspectives of the BSC model and adapted to the needs of the destination management organisation.

The relation to the financial aspect is crucial, regarding the public sources. Financing of tourism (Destination marketing management - DMM) in the Czech Republic was primarily dependent on the European resources in programming period of 2007 - 2013. The European Fund for Regional Development and European Social Fund were the principal financial tools for tourism financing. The program for the upcoming period of 2014 - 2020 does not include the destination marketing management anymore.

By adopting the BSC concept, the financial perspective covers only the basic indicators (pre- and post indicators), expressing the performance and ability to use the resources by the destination management organisation. Table 2 shows the point of view of the regional DMO, but the BSC could be moved up to the national level as well.

For the regional and national tourist organisation, the principle of 3Es can be adopted with regard to management effectiveness, efficiency and economy. The authors of this study projected the management of 3 Es in the BSC (and previous competitiveness model) in the following way:

- Effectiveness of the DMO - the result of activities of the DMO, thus what was achieved in terms of demand, residents and private sector ("doing the right things"). 
- Efficiency of the DMO - relation between inputs and outputs (“doing things right”), thus the extent to which objectives are met. The efficiency is expressed especially in the second financial and performance-related perspective (e.g. average expenditure for a trip).

- Economy of the DMO expresses the financial aspects of DMO activities, thus the cost of the resources on marketing and other activities and the value of the output ("doing things at the lowest price”).

The needs of visitors (consumers), residents (taxpayers and voters), private sector and public institutions have to be satisfied.

\section{Proposal for the Czech national tourist organisation (CzechTourism) in terms of practical use and monitoring of competitiveness model - BSC:}

\section{Step 1 - Clarification of the strategy and reaching a consensus}

The competitiveness model is very closely connected with strategy and the BSC model. Before starting the monitoring and evaluation process of various competitiveness indicators, the regional support for clearly defined destination strategy is necessary. The consensus is especially important in the Czech Republic since there is the decentralized system of the public administration in tourism. The interconnection between the national and regional BSC is necessary. Thus, the goals and their indicators have to be defined and interconnected at the national and regional level. Loyalty and conviction are necessary as well.

\section{Critical points - the national level:}

- The decentralized system of public administration in tourism in the Czech Republic; reluctance to define and measure the performance of the destination management organisations.

\section{Step 2 - Indicators and architecture of the BSC}

The main "architect" and working group for each perspective are recommended. The groups have to define the strategic goals and relevant indicators. For each indicator the information source (and methods) has to be defined. The goals and indicators in different perspectives have to be harmonized. The casual links among the perspectives are important for the strategy definition and management.

\section{Critical points - the national level:}

- Data availability, especially at the regional level; costs of data monitoring and evaluation; absence of complex information system in the Czech Republic; high diversity of tourism products (and resources) in a relatively small area. 


\section{Step 3 - Plan how to implement the BSC}

The implementation covers information on interrelations of the indicators, databases and information systems, communication of the BSC in the destination or DMO. The result is the new managerial system connecting the strategic and operational measurement.

The internal processes in the Czech national tourist organisation in terms of process setting, measuring and evaluation are needed.

\section{Critical points - the national level:}

- Political aspects at the national (and regional) level.

- Finding a reasonable ratio between the costs of data collection and evaluation and their value as a source for decision-making.

- Different aspects of the international and domestic market.

- Internal changes in the Czech national tourism organisation (time and source demanding activities).

To implement the BSC related to the process management, the $\mathrm{BSC}$ implementation plan has to be defined. The BSC implementation plan (national level) consists of four principal activities (adopted according to Kaplan \& Norton, 2005, p. 259):

1. BSC architecture - measurement program including a definition of the main strategic business units and their interconnection. The strategic business unit can be defined as the foreign representative office of the CzechTourism, region (administrative or marketing region), product or other criteria can be used to define the SBU.

2. Definition of the strategic goals in order to increase competitiveness with respect legislative framework, national tourism policy, regional data availability and consensus with the crucial private and public players.

3. Selection of a set of strategic (competitiveness) metrics with respect to regional level and capabilities.

4. BSC implementation plan at the level of tourist destination and CzechTourism based on the broad consensus of participating stakeholders.

\section{Discussion}

From the practical point of view of the regional or national tourism organisations, the total or "simple" values of various competitiveness indicators, covered by the competitiveness model, are not enough. The issue is how to project these indicators (or a set of indicators) into the managerial method.

The interconnection with the balanced scorecard (BSC) model seems to be the right way to use the competitiveness model in terms of strategic marketing and management of the destination. The link of the indicators goes through the BSC. 
Based on the analysis, the following assumptions can be proposed:

- Correlation between the existence of the destination management system / strategic management / destination marketing activities on one hand and competitiveness increasing on the other hand.

- Correlation between the existence of the destination management system / strategic management / destination marketing activities on one hand and benefits for the public / private sector on the other hand.

- Correlation between the existence of the destination management system / strategic management / destination marketing activities on one hand and residents' satisfaction on the other hand.

- Even though the (hard) resources represent the crucial asset of the destination and hence the necessary condition for tourism development, they are not a sufficient condition for achieving higher competitiveness of the destination. The strong presence of resources itself does not guarantee a higher level of competitiveness.

- High-powered human capital and innovation mean a higher level of competitiveness.

- More positive visitors' perception of the destination counts for better financial indicators in the private sector.

\section{Conclusion}

The BSC model represents the complement to the strategy map, not only in the private company (Kaplan \& Norton, 2008), but also in the tourist destination. The destination management system pursues the system performance and competitiveness and enables to connect not only the operational, but also the strategic processes and activities. The perspectives in the BSC concentrate on the partners, residents, financing, visitors, internal processes and learning and growth. However, they remind of the structure of the indicators specified by the OECD (Dupeyras \& MacCallum, 2013). The reason for adopting the BSC model is mainly that the model reflects the most substantial parameters of the competitiveness model since the tourism destination should be managed as a private company with some exceptions (e.g. Palatková, 2011). Therefore, the competitiveness model and the BSC model are closely connected. The connected perspectives and items are closely interconnected in both models. Important are the recipients of the implementation of both models, as well as the data availability. Moreover, attention should be paid to the connection to the managing and financing of the data collection and their processing.

Unfortunately, most of the indispensable data for the model construction regarding the Czech Republic regions are currently not available. However, the research design and survey tools are summarized, including the target groups, data collection method and proposed evaluation of the data, by using the measurement five-points scale. Considering the recipients (at the level of the regions / municipalities, DMO, private sector and residents), the main advantage consists in the methodology for competitive- 
Table 3 The BSC - destination at the regional (local) level

The Balanced Scorecard System (BSC) - DESTINATION - REGIONAL (LOCAL) LEVEL

\begin{tabular}{|c|c|c|c|}
\hline \multicolumn{4}{|c|}{ Global goal: Regional competitiveness increasing based on sustainable tourism. } \\
\hline \multicolumn{4}{|c|}{ 1. PARTNERS (STAKEHOLDERS) + RESIDENTS PERSPECTIVE } \\
\hline \multicolumn{4}{|l|}{ GOALS } \\
\hline $\begin{array}{l}\text { Satisfaction of the } \\
\text { public / private sector }\end{array}$ & $\begin{array}{l}\text { Quality of life - growth + } \\
\text { development indicators }\end{array}$ & $\begin{array}{l}\text { Balance Budget - } \\
\text { performance of the } \\
\text { marketing campaigns }\end{array}$ & $\begin{array}{l}\text { Business effect } \\
\text { measurement }\end{array}$ \\
\hline \multicolumn{4}{|l|}{ MEASUREMENT /METHOD } \\
\hline primary research & primary research & $\begin{array}{l}\text { audit of the marketing } \\
\text { campaigns }\end{array}$ & primary research \\
\hline \multicolumn{4}{|c|}{ TYPE OF INDICATORS (examples) } \\
\hline $\begin{array}{l}\text { number of official partners } \\
\text { (public / private sector) + } \\
\text { satisfaction rate }\end{array}$ & $\begin{array}{l}\text { residents' perception of } \\
\text { tourism benefits + attitude } \\
\text { to tourism }\end{array}$ & $\begin{array}{l}\text { relevant indicators (OHT, } \\
\text { OTS, TVR, PPC, CTR, CPA } \\
\text { and other) }\end{array}$ & $\begin{array}{l}\text { turnover generated by the } \\
\text { distribution (sales) of the } \\
\text { DMO }\end{array}$ \\
\hline survival rate of companies & satisfaction of residents & $\mathrm{ROI}$ - return on investment & number of clients \\
\hline \multicolumn{4}{|c|}{ 2. FINANCIAL + PERFORMANCE-RELATED PERSPECTIVE } \\
\hline \multicolumn{4}{|l|}{ GOALS } \\
\hline Price competitiveness & Visitors'consumption & $\begin{array}{l}\text { Financial indicators in the } \\
\text { private sector (tourism) }\end{array}$ & Tourism economic impact \\
\hline \multicolumn{4}{|l|}{ MEASUREMENT /METHOD } \\
\hline $\begin{array}{l}\text { on-line survey focusen on } \\
\text { accommodation rates }\end{array}$ & $\begin{array}{l}\text { primary research / } \\
\text { secondary data (CSO) }\end{array}$ & $\begin{array}{l}\text { primary and secondary } \\
\text { quantitative research }\end{array}$ & $\begin{array}{l}\text { primary research / regional } \\
\text { TSA }\end{array}$ \\
\hline \multicolumn{4}{|c|}{ TYPE OF INDICATORS (examples) } \\
\hline average rate in $\mathrm{CAE}$ & $\begin{array}{l}\text { tourists / excursionists } \\
\text { consumption }\end{array}$ & $\begin{array}{l}\text { turnover in selected sample } \\
\text { of CAE }\end{array}$ & impact on GDP \\
\hline $\begin{array}{l}\text { average rates of selected } \\
\text { services }\end{array}$ & $\begin{array}{l}\text { average expenditure for a } \\
\text { trip incl. the structure of the } \\
\text { expenditure }\end{array}$ & $\begin{array}{l}\text { ADR / RevPar in selected } \\
\text { sample of CAE }\end{array}$ & impact on employment \\
\hline \multicolumn{4}{|l|}{ 3. VISITOR PERSPECTIVE } \\
\hline \multicolumn{4}{|l|}{ GOALS } \\
\hline Loyalty of the visitors / CRM & Satisfaction of the visitors & $\begin{array}{l}\text { Quantity and quality of } \\
\text { demand }\end{array}$ & $\begin{array}{l}\text { Perceived brand value of the } \\
\text { region }\end{array}$ \\
\hline \multicolumn{4}{|l|}{ MEASUREMENT / METHOD } \\
\hline $\begin{array}{l}\text { qualitative / quantitative } \\
\text { research / benchmarking }\end{array}$ & $\begin{array}{l}\text { primary research / } \\
\text { benchmarking / analysis of } \\
\text { the clients'review }\end{array}$ & $\begin{array}{l}\text { consumer behaviour } \\
\text { research }\end{array}$ & $\begin{array}{l}\text { consumer behaviour } \\
\text { research }\end{array}$ \\
\hline \multicolumn{4}{|c|}{ TYPE OF INDICATORS (examples) } \\
\hline rate of repeating visits & reasons of satisfaction & $\begin{array}{l}\text { principal information source } \\
\text { (decision making process) }\end{array}$ & $\begin{array}{l}\text { value advantage for } \\
\text { (potential) vi sitors }\end{array}$ \\
\hline $\begin{array}{l}\text { average daily attendance of } \\
\text { the } D M O \text { web sites }(R U)\end{array}$ & reasons of dissatisfaction & $\begin{array}{l}\text { category and class of } \\
\text { overnight facilities }\end{array}$ & brand vitality \\
\hline $\begin{array}{l}\text { average time spent in the } \\
\text { sites / modules (ATS) }\end{array}$ & $\begin{array}{l}\text { willingness to recommend } \\
\text { the selected regions to } F \text { \& } R\end{array}$ & $\begin{array}{l}\text { number of nights in CAE } \\
\text { (CSO) / IAE - related to 2nd } \\
\text { perspective }\end{array}$ & brand confidence \\
\hline
\end{tabular}




\begin{tabular}{|c|c|c|c|}
\hline \multicolumn{4}{|c|}{ 4. INTERNAL PROCESS PERSPECTIVES - NEW AND INNOVATION PROCESSES (Action Plan) } \\
\hline \multicolumn{4}{|l|}{ GOALS } \\
\hline $\begin{array}{l}\text { Tourism planning and } \\
\text { Financing }\end{array}$ & $\begin{array}{l}\text { Customer management } \\
\text { process }\end{array}$ & Innovation process & Resources management \\
\hline financing (allocation) & demand monitoring system & product innovation & $\begin{array}{l}\text { resources allocation }+ \\
\text { resources performance } \\
\text { monitoring }\end{array}$ \\
\hline quality management & $\begin{array}{l}\text { continuous research + } \\
\text { monitoring }\end{array}$ & process innovation & $\begin{array}{l}\text { information acquiring and } \\
\text { management / sharing }\end{array}$ \\
\hline $\begin{array}{l}\text { information + knowledge } \\
\text { sharing (CRM - partners) }\end{array}$ & CRM & marketing innovation & sustainability \\
\hline $\begin{array}{l}\text { Integrated information } \\
\text { system (incl. MIS, CRM) }\end{array}$ & Product development & Distribution strategy & $\begin{array}{l}\text { Communication (Brand) } \\
\text { strategy / Brand value } \\
\text { management }\end{array}$ \\
\hline \multicolumn{4}{|c|}{ 5. LEARNING AND GROWTH PERSPECTIVE } \\
\hline \multicolumn{4}{|l|}{ GOALS } \\
\hline Human capital & Organisation capital & Information capital & Technological capital \\
\hline $\begin{array}{l}\text { qualified and motivated } \\
\text { colleagues }\end{array}$ & $\begin{array}{l}\text { system of destination } \\
\text { marketing management }\end{array}$ & $\begin{array}{l}\text { marketing information } \\
\text { system }\end{array}$ & $\begin{array}{l}\text { ICT in communication and } \\
\text { mkt research }\end{array}$ \\
\hline
\end{tabular}

Source: own figure based on Palatková et al. (2014)

ness measurement. It is connected with the DMO performance (management tool). The DMO needs feedback to be able to launch more effective strategies and to make the better use of regional comparative advantages. The economic and non-economic tourism effects must be put into practice, with impact on the private sector and residents. At the level of the National Tourism Destination, CzechTourism achieves a set of basic performance indicators at the regional level as a supportive tool to design national marketing strategies for domestic, as well as incoming tourism, including their financial support. Furthermore, the monitoring of the determined indicators should enable more efficient management of the public resources (Palatková et al., 2014).

The application of the model is limited by the unavailability of data, the time and space comparison among the regions and the maintenance of the continuity of monitoring. The relevant relative indicators have to be defined to keep the model dynamic in the long term. In addition, only the indicators directly connected to tourism are included in the competitiveness model and in the BSC. The indicators will be grouped by urgency as classified by the OECD (Dupeyras \& MacCallum, 2013) into three groups - the core indicators, supplementary and future development indicators. Each indicator is described by its aim, interpretation, weights and other attributes (incl. financial costs).

Considering the purpose and limits of the model and the present situation in the field of the destination marketing management in the Czech Republic, benefits of the competitiveness model and BSC model for the national (and regional) level can be summarized as follows: 
- Relevant determination of the strategic goals and indicators of success rate.

- More effective decision on the (financial) resources allocation.

- Ability to argue tourism importance with the politicians.

- Transparent implementation of the strategic documents and policies.

- Marketing activities measurement performance at the regional level. Critical points can be summarized as follows:

- Financial costs and demands of other resources - a number of indicators.

- Data availability over a long period.

- Political aspects.

It is also important to mention the individual costs of the DMO (public budget), e.g. the intense pressure on the better coordination and communication and on the transparency of providing and sharing of information. Furthermore, an increase of the costs of marketing research and growing demand on the destination information system, in terms of capacity, structure, number and groups of users, commercialization of the system and other aspects must be noted. In addition, rising requirements on management and control of the system and process of the destination marketing management. As it has been already mentioned, the results of the paper are part of the whole project. The next step would be the performance of the research, testing of the model in practice and its implementation.

\section{References}

Adler, M. D., \& Posner, E. (2001). Cost-Benefit Analysis: Legal, Economic, and Philosophical Perspectives. Chicago: The University of Chicago.

Barney, J. (1991). Firm Resources and Sustained Competitive Advantage. Journal of Management, 17(1), 99-120. DOI: 10.1177/014920639101700108

Blanke, J., \& Chiesa, T. (Eds.). (2013). The Travel and Tourism Competitiveness Report 2013. Reducing Barriers to Economic Growth and Job Creation. Geneva: World Economic Forum. Retrieved from http://www3.weforum.org/docs/WEF_TT_Competitiveness_Report_2013.pdf

Cunha, S. K., \& Cunha, J. C. (2005). Tourism Cluster Competitiveness and Sustainability: Proposal for a Systemic Model to Measure the Impact of Tourism on Local Development. Brazilian Administration Review, 2(2), 47-62.

Dupeyras, A., \& MacCallum, N. (2013). Indicators for Measuring Competitiveness in Tourism: A Guidance Document. OECD Tourism Papers, 2013/02. Paris: OECD Publishing. DOI://dx.doi. org/10.1787/5k47t9q2t923-en

Dwyer, L., \& Kim, C. (2003). Destination competitiveness: determinants and indicators. Current Issues in Tourism, 6(5), 369-414. DOI: 10.1080/13683500308667962

Kaplan, R. S. (2012). The balanced scorecard: comments on balanced scorecard commentaries. Journal of Accounting E Organizational Change, 8(4), 539-545. DOI: 10.1108/18325911211273527

Kaplan, R. S., \& Norton, D. P. (2004). Strategy Maps: Converting Intangible Assets into Tangible Outcomes. Boston: Harvard Business School Press. 
Kaplan, R. S., \& Norton, D. P. (2005). Balanced scorecard. Strategický systém měreni výkonnosti podniku (Balanced scorecard. Strategic system of measuring business performance). Prague: Management Press.

Kaplan, R. S., \& Norton, D. P. (2008). Efektivni systém řizeni strategie (Strategy of the effecient system of management). Prague: Management Press.

Lee, C. F., \& King, B. (2009). A determination of destination competitiveness for Taiwan's hot springs tourism using the Delphi technique. Journal of Vacation Marketing, 15(3), 243-257. DOI: $10.1177 / 1356766709104270$

Mishan, E. J., \& Quah, E. (2007). Cost-Benefit Analysis. Oxon: Routledge.

Palatková, M. (2011). Marketingový management destinaci (Marketing destination management). Prague: Grada Publishing.

Palatková, M., Zichová, J., \& Hrubcová, G. (2014). Tourism competitiveness of the Czech Republic regions and the possibility of the marketing measures performance evaluation using the BSC method [online]. Prague: University of Business in Prague. Retrieved from http://www.tsf2014prague. cz/Paper\%204.2_Monika\%20Palatkova_CZ.pdf

Poon, A. (1993). Tourism, Technology and Competitive Strategies. Wallingford: CABI Publishing.

Porter, M. E. (1990). The Competitive advantage of Nations. New York: Free Press.

Porter, M. E. (1993). Konkurenčni výhoda (Competitiveness advantage). Prague: Victoria Publishing, a. s.

Porter, M. E. (1994). Konkurenčni strategie (Competitiveness strategy). Prague: Victoria Publishing, a. s.

Ritchie, J. R. B., \& Crouch, G. I. (2003). The competitive Destination. A Sustainable Tourism Perspective. Wallingford: CABI Publishing.

Schumpeter, J. A. (2004). Kapitalismus, Socialismus a Demokracie (Capitalism, Socialism Ẽ Democracy). Brno: Centrum pro studium demokracie a kultury.

Vanhove, N. (2005). The economics of tourism destinations. Oxford: Elsevier Ltd. 